\title{
A Quintessential Lesson from European Union Integration to African Union
}

\author{
Dr. Hasan Korkut \\ International University of Sarajevo \\ Endris Mekonnen Faris \\ International University of Sarajevo
}

\begin{abstract}
The African Union -a multipurpose cooperation platform which most believe inspired by the European Union- came to exist to transform the continents fate into a prosperous one. European Union unprecedentedly becomes the crucial factor to speed up the Europe's integration. European Union is an economic community and was not meant, first, a political one. Hence European Union can be a quintessential lesson for the African Union if the later understands the formers achievement came because of the exclusive emphasis given to the economic approach. The paper empirically argues that economic integration leads to an outright continental political unity. Accordingly the continent's integration can only be achieved when economic approach is given prior emphasis. The political approach is a default which by nature follows the achievements gained from economic approach.
\end{abstract}

Keywords: European Union, African Union, Economic approach integration, Political approach.

\section{INTRODUCTION}

The globe, in general, is living in extraordinary period of cooperation and is promptly changing into a likelihood of small vicinity than any other time before. The brand of cooperation varies across the world so do the level of achievements those cooperation have so far championed. The yearly book of international organizations is a comprehensive resource of over 68,000 international organizations. Working under official name called Union of International Associations it developed a tool where in the accessibility of numbers of cooperation platforms has been made possible. The tool includes detailed information on over 38,000 active and 30,000 dormant international organizations from 300 countries and territories - including intergovernmental (IGOs) and international nongovernmental organizations (INOGs) noticing further that approximately 1,200 new organizations are added each year. ${ }^{1}$

The economic cooperation has by far helped for the some prosperous segments of the world to emerge better than of any

${ }^{1}$ Union of International Associations. (n.d.). Retrieved June 16, 2016, from http://www.uia.org/yearbook 
other kinds of cooperation either by single-purpose or/and multipurpose organizations. Solely political oriented organizations, in all parts of the world have been achieving their respective purposes but remain source of tension, unanimity and disintegrations. Ordinary citizens living in economy-led cooperation have substantially been observed to change their life condition contrary to ordinary citizens living in politics-led cooperation, such as Africa.

Both the European Union (EU) and African Union (AU), the focus of this paper, as members of the cooperation generation are meant to serve such cooperation purpose. The former exclusively represents a single purpose mission, i.e. the economy. The economic identity of the Union is not the only and the lasting purpose of its existence. Starting off as an economic community, then growing into a new kind of federalist supra-state, 28 countries today have come together to participate in the blurring of national borders, achieving more success in market integration than foreign and security policy. ${ }^{2}$

This paper on the basis of empirical comparison tries to show the exemplary of the European Union to African Union in such a way that the later could speed up and succeed its integrity agenda by giving priority to an economic approach that the former proved it feasible.

\section{TRANSFORMATION TO AU}

\subsection{Main justifications}

The meeting from July 2-11, 2001 in Lusaka, Zambia was concluded with an official approval to transform the Organization of African Unity (OAU) into a new one-the African Union (AU). But the decision was not a result of an overnight discussion, in fact leaders concerned more have been pondering for the demand to change the fate of the then virtually 40 years old organization. Apart from the justifications coming from the authorities, scholars attempted to forward their own analytical reasoning as to why the move has been launched. This paper argues the following two points profoundly important justifications. They could potentially be related to the fate of the ordinary Africans as far as their longing to get relieved from desperate life condition prevailing in the continent.

Globalization, a new phenomenon, offered the world the stoutest centripetal force whose sole element of attraction is economy. It showed the world, by hook or by crook, the substantial possibility of its merging into a local and small market. Unlike other global phenomenon globalization was so fast and deemed to have no excuse if one is not comply with it without delay. Many countries, particularly in the third world, woke up to find globalization

${ }^{2}$ Stadnik, S. (2016, May 12). A Comparative Historical Study of the Development of a European Army. E-International Relations. Retrieved May 16, 2016 
in their dominion without having appropriate policies to deal with it. Africans confronted globalization and its impacts with no meaningful tool to neither get benefited from nor to cope up with. The scattered endeavors here and there at national level as a reaction failed to outdo the impact caused by the globalization at the continental level. The tool that was supposed to challenge the phenomenon at the continental level with a harmonized approach and relevant policies lacked the organizational formula. Because of this Africa is worse off economically today than it was at the time of the founding of the OAU. ${ }^{3}$ The Organization for African Unity functionally existed as a leading effort to protect the unity and sovereignty of its member states. That however was a tool to shield from the intrusion of political authority by outsiders. This built up the demand to sour to the level that there should be a transformation of the old fashion organization to the one that fits the dynamic world.

The second, but imperative rational is the desire to bring about prosperity achieved by other horizontally equivalent organizations particularly the European Union. The record achievements of the EU have put the supranational cooperation platform at the top of contemporary organizations. For ordinary people in the continent, where the EU membership enclaves, the cooperation added value in their life. The changes observed have resulted in significant improvements in economy, politics and social and culture in virtually all EU membership countries. The role played by the EU in its specialized economic field became center of interest that countries within the continent are longing to get benefited from by joining it. Such role has long been missed in the African continent basically because the old organization- OAU- was not essentially shaped as such.

\section{KEY FEATURES ATTRIBUTED TO OAU AND AU}

The two organizations representing the African continent in the global political, economic and social realm could characteristically be attributed with distinguishing features. The now dissolved OAU, for instance was particularly established on the basis of pan-Africanism sentiment. The then pan-African giant and charismatic visionaries were in the front to lead the continent wide strong emotion, pride and hope to change into a strong organization of unity. In that sense the pan-Africanist OAU was typical not to follow any other horizontally equivalent organization. AU replacing OAU on the other hand hugely lack the emotional sentiment and consequently pan-Africanism exists in its very low level. African Union, in fact, was established on the basis

\footnotetext{
${ }^{3}$ Bujra, A. (2002). Africa: Transition From the OAU to the AU [pdf document]. Retrieved from Lecture Notes, May 13, 2016 http://www.dpmf.org/meetings/ FromOAUAU.html
} 
of business like sentiment whose launch was moderate and muted, with little stimulating rhetoric or enthusiasm.

Objectivewisethetwoiconicorganizations differdistinguishably. Organization for African Unity objectively was featured as front bringing hands together to liberate lands and powers from mainly European colonizers. Most of the then leaders of the countries in the continent were freedom fighters with unanimous vision, which is independence. African Union had clearly envisioned further economic integration. The following table depicts in brief how easily these two organizations are distinguishable objective wise and most of the clauses in AU's objective included the word "economic".

Table 1: OAU's and AU's Featuring Objectives

\begin{tabular}{|c|c|c|}
\hline & OAU & $\mathbf{A} \mathbf{U}$ \\
\hline 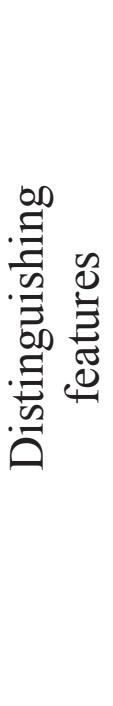 & $\begin{array}{l}\text { The Organization shall } \\
\text { have the following pur- } \\
\text { poses: }{ }^{1} \\
\text { (a) To promote the } \\
\text { unity and solidar- } \\
\text { ity of the African } \\
\text { States; } \\
\text { (b) To defend their sov- } \\
\text { ereignty, their terri- } \\
\text { torial integrity and } \\
\text { independence; } \\
\text { (c) To eradicate all } \\
\text { forms of colonial- } \\
\text { ism from Africa; }\end{array}$ & $\begin{array}{l}\text { The objectives of the Union shall } \\
\text { be to: }{ }^{2} \\
\text { (a) Accelerate the political and } \\
\text { socio-economic integration of } \\
\text { the continent; } \\
\text { (b) Establish the necessary con- } \\
\text { ditions which enable the con- } \\
\text { tinent to play its rightful role } \\
\text { in the global economy and in } \\
\text { international negotiations; } \\
\text { (c) Promote sustainable develop- } \\
\text { ment at the economic, social } \\
\text { and cultural levels as well } \\
\text { as the integration of African } \\
\text { economies; }\end{array}$ \\
\hline
\end{tabular}

Source: OAU's Charter and AU's Constitutive Act: Authors' Compilation

\section{SIMILARITIES BETWEEN AU AND EU}

The African Union, which came into existence in 2002, seems in some ways to be a copy of the European Union ${ }^{4}$ and aims the political and economic integration of the African states. ${ }^{5}$ First of all, there is the obvious use of "Union" in the name. It seems a trivial issue paving a reductionist approach. The case, however, is so much so important. The preference to use the suffix "Union" was a deliberate and an answer to the desire coming from EU to setup,

\footnotetext{
${ }^{4}$ Siaroff, A. (2007). Following in Europe's Footsteps? The African Union and Integration in Africa. Paper presented at the Biannual Congress of the European Union Studies Association, Montreal, Quebec. Retrieved May 13, 2016, from http://aei. pitt.edu/8034/1/siaroff-a-06c.pdf

${ }^{5}$ Bostan, Z. (2013). 'Another false dawn for Africa?' An assessment of NEPAD. E-International Relations. Retrieved May 13, 2016, from http://www.e-ir.info/2011/07/19/'another-false-dawn-for-africa-'-discuss-this-assessment-of-nepad/
} 
from the outset, the coming organization as parallel to deal with issues in continental level. Secondly, the institutions of the African Union parallel those of the European Union.

Very specifically, the African Union has a Pan-African Parliament, an executive African Commission, an African Court of Justice, an Executive Council (to match the European Union's Council of Ministers), and - at the apex - the Assembly of the African Union, grouping its political leaders and meeting at summits (as per the European Council). Third and finally, the future plans of the African Union include other parallels, in particular an African Central Bank. ${ }^{6}$

To sum up the EU and the AU have strikingly similar features. This is no surprise, considering that much of the AU structure was built upon the EU model. The following table shows that, with a few exceptions, the $\mathrm{AU}$ is almost the mirror image of the EU. ${ }^{7}$

\section{WHAT BRANDSEU AS ANEFFECTIVECOOPERATION PLATFORM?}

The European Union paves economic approach ahead of political approach to realize the continents integration. The union has been at the heart of the European integration, converging countries once in conflict back in history. EU serves as a key trading and investment partner across Europe and as a powerful catalyst for fundamental economic and governance reforms by many entrants and aspirants. An economically prosperous union has managed to take over some sovereign powers of member states. The later substantially convinced that transferring their power to the supranational institution contributes to the better and common benefits of all. Had there been an attempt to integrate the continent paving the political approach the fate of the continent would have been different by far.

\footnotetext{
${ }^{6}$ Siaroff, A. (2007). Following in Europe's Footsteps? The African Union and Integration in Africa. Paper presented at the Biannual Congress of the European Union Studies Association, Montreal, Quebec. Retrieved May 13, 2016, from http://aei.pitt.edu/8034/1/siaroff-a-06c.pdf

${ }^{7}$ Z. Sore, Z. S. (2010). Establishing Regional Integration: The African Union and the European Union. Macalester International, 25(13). Retrieved May 16, 2016, from http://digitalcommons.macalester.edu/macintl/vol25/iss1/13
} 
Table 2: Structural Resemblance of the $\mathrm{EU}^{8}$ and $\mathrm{AU}^{9}$

\begin{tabular}{|l|l|}
\hline \multicolumn{1}{|c|}{ European Union } & \multicolumn{1}{c|}{ African Union } \\
\hline $\begin{array}{l}\text { European Council (Heads of } \\
\text { States) }\end{array}$ & $\begin{array}{l}\text { Assembly of the Union (Heads of } \\
\text { States) }\end{array}$ \\
\hline $\begin{array}{l}\text { Council of the European Union } \\
\text { (Ministers) }\end{array}$ & Pan-African Parliament \\
\hline European Parliament & Pan-African Parliament \\
\hline $\begin{array}{l}\text { Committee of Permanent Repre- } \\
\text { sentatives }\end{array}$ & $\begin{array}{l}\text { Permanent Representatives Com- } \\
\text { mittee }\end{array}$ \\
\hline $\begin{array}{l}\text { The Financial Institutions } \\
\text { - European Central Bank }\end{array}$ & $\begin{array}{l}\text { The Financial Institutions } \\
\text { European Investment } \\
\text { Bank }\end{array}$ \\
\hline
\end{tabular}

Source: Treaty establishing a Constitution for Europe and African Union Constitutive Act: Authors' Compilation

Passing through different phases after its foundation, the union has firmly assured the world as an economic branded cooperation platform. Securing the economic benefit of its members by getting involved in a common and single market, irrespective of the status and a country's level of advancement, is the core objective of the union. There have been varieties of approaches that scholars have developed and used to measure the empirical changes countries in the EU scored. The measures essentially focus on whether countries indeed get economically benefited or not in their membership of the European Union.

The Synthetic Counterfactuals Method (SCM), pioneered by Abadie and Gardeazabel (2003) has been employed to substantiate empirically the economic benefit member states in the EU have been generating. Accordingly, countries labeled rich and poor are taken into account to measure their GDP after they joined the union and if they were, supposedly, not members at all. Nauro F. Campos, Fabrizio Coricelli and Luigi Moretti ${ }^{10}$ used the SCM and have come Inquiry up with findings that clearly show the consequences of joining EU 2016/1 as far as the respective country's GDP is concerned. Preferably UK, Denmark, Irland, Portugal and Spain are selected for their change in GDP graphically is analyzed. The simple graph contains two lines

\footnotetext{
${ }^{8}$ Treaty establishing a Constitution for Europe. Retrieved May 16, 2016 from http://eur lex.europa.eu/legal\%20content/en/txt/?uri=uriserv:oj .c_2004.310.01.0001.01.eng\&toc $=$ oj:c:2004:310:toc

${ }^{9}$ Constitutive Act of the African Union: http://www.au.int/en/sites/default/files/ Constitutive Act_EN.pdf

${ }^{10}$ Campos, F., N., Coricelli, F. and Moretti, L. (2016). The eye, the needle and the camel: Rich countries can benefit from EU membership. VOX, CEPR's Policy Portal. Retrieved May 16, 2016 from http://voxeu.org/print/10502
} 
one broken the other solid. The broken line represents estimated GDP if the country had not been a member of the Union.

Figure 1: GDP evaluation of Denmark and UK
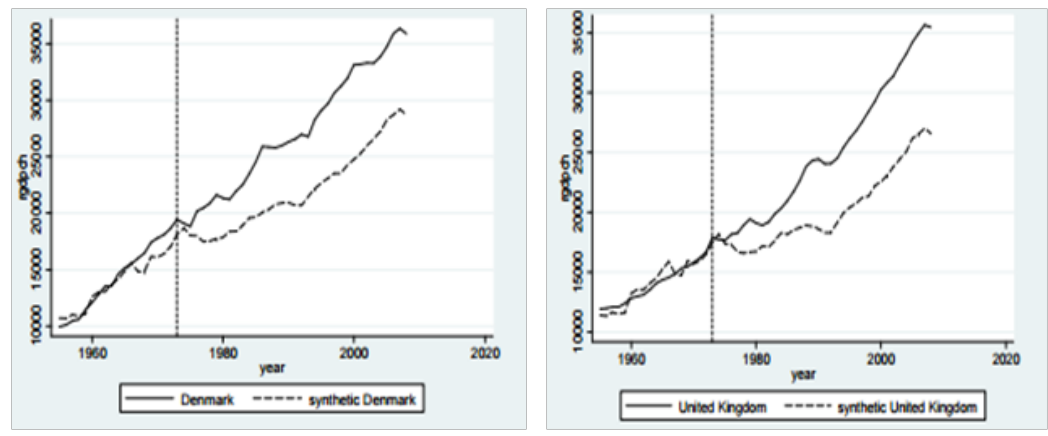

Source: Nauro F. Campos, Fabrizio Coricelli and Luigi Moretti, 2016 ${ }^{11}$

Figure 1 depicts that country, such as UK and Denmark that were economically much better than the rest of member states in the union have been getting benefited by joining the EU. The result as shown in the graph would be quite to the contrary if the states stayed away from EU membership.

Figure 2 depicts both countries' better payoff in their membership to the EU. The graph exponential elevated from its lower level before the countries joined the union and continue to grow so long the countries maintain their membership.

\section{LESSON FOR AFRICA FROM THE EU INTEGRATION \\ 6.1. Economic Approach for an Effective Integration}

Transferring sovereign political power willingly to an organization to bring about integration is not such simple imagination. It is unbounded by borders and it feels similar whether in Europe or Africa. However EU has managed to break this chain by implementing economic approach rather than political approach. By successfully realizing the vision to bring the Europe in to a single market where in states can freely get involved and benefited from EU has achieved to the great extent to take over some of the important sovereign powers of member states.

\footnotetext{
${ }^{11}$ Campos, F., N., Coricelli, F. and Moretti, L. (2014). Economic Growth and Political Integration: Estimating the Benefits from Membership in the European Union Using the Synthetic Counterfactuals Method. Forschungsinstitut zur Zukunft der Arbeit Institute for the Study of Labor: Bonn. Retrieved May 16, 2016 from http://anon-ftp.iza.org/dp8162.pdf
}

Inquiry 97 
Figure 2: GDP evaluation of Portugal and Spain
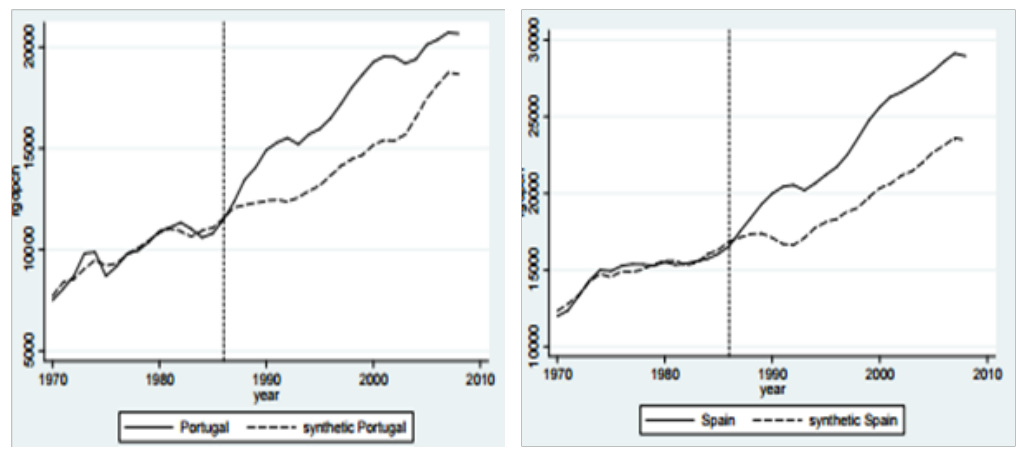

Source: Nauro F. Campos, Fabrizio Coricelli and Luigi Moretti, 2016

Economic approach is viable approach that states in Africa could accept to speed up the continent's integration. Political approach would never be a viable formula in Africa. In a very widely understandable feeling across the continent no single state/ country believes its political system is far behind the other state/ country. In other word no other state/country feels better to lead others considering its political system is exemplary by large. No political system as a role model exists in the continent to be shared implies there is no any political approach to successfully be adopted to integrate the continent. The economic approach, on the other hand works. EU is a quintessential in this regard.

Three levels of empirical analysis can be employed in order to assert the aforementioned claim, namely continental level: here the paper refers countries; country level: here the paper refers the state; and individual level: here the paper refers politicians.

\subsubsection{Continental level}

EU's integration started from the western part of the continent as an economic bloc. It expanded, then, to the other part of the continent in 1970s to include other European countries convinced of the achievements gained by the founding members. Now that small economic community is no more confined to a corner rather became a continental concern. The achievement has led to create greater sense of convergence manifested as a demand to voluntarily integrate into a one but larger single market. The continent wide prosperity has become persuasive tool to win heart and soul of former political rivals. This has enabled the unity to draft continent wide and politically meaningful laws, regulations and policies. Now a day the countries embraced by the unions are significantly represented globally as a singly political unity governed, for instance, by common foreign and defense policies. What started as a small economic community culminated, finally, an economically harmonized, big and prosperous political union. 
The same formula can be applied in Africa as it needs continent wide initiation. Taking the leading role, AU should put economic approach as a prior agenda by casting the very conflictual and separating political approach aside. Policies that can promote and speed up the realization of free trade with in a single market that could embrace the whole continent should be developed.

\subsubsection{Country level}

Economic prosperous integration is a common platform for a bitterly enemy countries to come together and solve their century old political disputes, conflicts even war. EU is serving as such means to bring formerly bitter enemies together and make business. An economic integration is the less hesitant approach for the state to confer some of its sovereignty to the supranational institutions. Having practically observed the prosperity the supranational entity has gained member state will find the situation favorite enough to compromise some of the exclusive a national level power. This encourages other non-member states to pave the same. Practically this would give substantial result in Africa, if the integration effort put the economical approach ahead. Conferring sovereignty would be a big deal while it's the most untouchable issue otherwise.

\subsubsection{Individual level}

Politicians and politics in advanced countries, particularly in EU member countries are interrelated in a proper manner. A politician holding public office, for instance, if fails to carry out duty, can easily resign or transform the power to whoever to come peacefully. Quitting political authority does not imply anything further and life continues ordinarily. The opposite is true in Africa. Why is the question? Africa is often mentioned with the leaders reigning for longest possible period of time. The late Muammar Ghadafi was in power for nearly 42 years before ousted and killed, Mugabe of Zimbabwe since 1987, Mussieveni of Uganda has been in power since 1986, Oumar Al-Bashir of Sudan has been in power since 1989, Mumabark of Egypt ruled Egypt form 30 yearsare only few worth mentioning.

One of the reasons why politicians in Africa resist giving up or transferring power is they would not have a secured life after quitting power in office. Unlike politicians particularly in Europe, politicians in Africa have no any way to go after power. To live until their death in power is the option less option. A politician holding public office in Europe will not be hesitant to resign or to quit for any case that prevents him/her to stay in office anymore. The question of the coming fate regarding how to afford life may not cross his/her mind. The opposite is true in many of the countries in Africa. Life after office/ power is a nightmare. For many state-men, politicians in Africa following their powers no to exist anymore they ended 
in jail, exile or death. Rare occasion are known in the continent politicians to rejoin the ordinary society and live together in peace and tranquility after they abandoned power in any way. That is why peaceful power transition is a sort of miracle in the continent.

An economically integrated and prosperous Africa, taking lesson from EU, will not have a space to accommodate such resistant and dictator politicians. Quitting or power transferring will not be such an issue any more.

\section{CONCLUSION}

$21^{\text {st }}$ Century is more convenient for pro unity, togetherness and integration. In all these both small and larger actors, for instance, in a particular region can secure their relative gains. Consequently the region becomes prosperous; peaceful that definitely affects the globe. A united (an integrated) region in its strength, and success to be prosperous will not only be a confined issue to the region per se but also inevitably would have an extended effect to affect political, economic and social affairs of other states, other regions and the globe at large.

Quite a few efforts have been developed and expired; some still exist, without positively impacted to change the livelihood of ordinary Africans. Millions of Africans still live in sever poverty while paradoxically the global production is consuming the infinite and varieties of raw materials from the continent. When a horizontally equivalent organization-EU- becomes source of prosperous there is no reason that $\mathrm{AU}$ to fail to do so. A formula applied to bring people in one continent into a strong unity should also function the same way to produce a better result given some sort of customizations are taken onto considerations.

As discussed in this paper a more united and prosperous Africa can only emerge when economic approach, rather than political approach is given prior attention. African Union, as the sole and iconic cooperation platform should coordinate efforts from all the corners of the continent. The work seems simplified as each of subregional blocs are mainly organized on the basis of free trade that lead to regional integration. Economic Community of West African States (ECOWAS) in the West, Common Market for Eastern and Southern Africa (COMESA) in the southeast, Economic Community of Central African States (ECCAS) in the center and East African Community (EAC) in the east are by far crucial segments. Each of the sub-regional blocs should harmonize their economic platforms and formulas envisioning future integration so that the future continent-wide integration would very much be simple. 


\section{REFERENCES}

Ayittey. B. N. George (2010). The United States of Africa: A Revisit. American Academy of Political and Social Science, 632, 86-102. Retrieved May 13, 2016, from http://www.jstor.org/stable/27895950

Babarinde, O. (2007). The EU as a Model for the African Union: the Limits of Imitation. Jean Monnet/Robert Schuman Paper Series, 7(2). Retrieved May 16, 2016 from http://www6.miami.edu/eucenter/BabarindeEUas Modellong07edi.pdf

Balassa, B. (1961). The Theory of Economic Integration. Richard Irwin: Homewood. Bedjaoui, M. (n.d.). From the Pan-Africanist Movement to the African Union Brief Historical Overview of Steps to African Unity. The African Union: Legal and Institutional Framework, 7-23. doi:10.1163/9789004227729_003

Bostan, Z. (2013). 'Another false dawn for Africa?' An assessment of NEPAD. E-International Relations. Retrieved May 13, 2016, from http://www.e-ir.info/2011/07/19/\%E2\%80\%98another-false-dawn-forafrica-\%E2\%80\%99-discuss-this-assessment-of-nepad/

Braveboy-Wagner, J. A. (2009). Institutions of the global south. Milton Park, Abing don, Oxon: Routledge.

Bujra, A. (2002). Africa: Transition from the OAU to the AU [PDF document]. Re trieved from Lecture Notes, May 13, 2016 http://www.dpmf.org/meetings/FromOAUAU.html

Campos, F., N., Coricelli, F. and Moretti, L. (2014). Economic Growth and Political Integration: Estimating the Benefits from Membership in the European Union Using the Synthetic Counterfactuals Method. Forschungsinstitut zur Zukunft der Arbeit Institute for the Study of Labor: Bonn.

Retrieved May 16, 2016 from http://anon-ftp.iza.org/dp8162.pdf

Campos, F., N., Coricelli, F. and Moretti, L. (2016). The eye, the needle and the camel: Rich countries can benefit from EU membership. VOX, CEPR's Policy Portal. Retrieved May 16, 2016 from http://voxeu.org/ print/10502

Carpenter, M. and Dunung, P., S. (2015). International Business: Opportunities and Challenges in a Flattening World, v. 2.0. Retrieved May 12, 2016 from http://2012books.lardbucket.org/pdfs/challenges-and-opportun ities-in-international-business.pdf

European Center for Development Policy Management. (2010). Building the African Union An assessment of past progress and future prospects for the African Union's institutional architecture (Policy and Man agement Report 18). Maastricht: ECDPM. Retrieved May 15, 2016 from www.ecdpm.org/pmr18

Furtak, F. T. (2015). Integration in Regional Organizations ? A Comparison of EU, AU, OAS, and ASEAN. Journal of Civil \& Legal Sciences Civil Legal Sci, 04(02). doi:10.4172/2169-0170.1000146

Karangizi, S. (n.d.). The Regional Economic Communities. The African Union: Legal and Institutional Framework, 231-249. doi:10.1163/9789004227729_013

McCormick, J. (1999). Understanding the European Union: A Concise Introduc tion. London: Macmillan Press ltd.

Moghadam, R. (2014). Europe's Road to Integration. International Monetary Fund Finance \& Development. 51(1). Retrieved May 16, 2016, from http://www.imf.org/external/pubs/ft/fandd/2014/03/moghadam.htm

Peters, W. (2010). The quest for an African economic community: Regional in tegration and its role in achieving African unity - the case of 
SADC (Doctoral dissertation) [Abstract].

Siaroff, A. (2007). Following in Europe's footsteps? The African union and integ ration in Africa. Paper presented at the Biannual Congress of the European Union Studies Association, Montreal, Quebec. Retrieved May 13, 2016, from http://aei.pitt.edu/8034/1/siaroff-a-06c.pdf

Sicurelli, D. (2010). The European Union's Africa Policies: Norms, Interests and Impact. Ashgate Publishing Limited: Farnham.

Stadnik, S. (2016, May 12). A Comparative Historical Study of the Development of a European Army. E-International Relations. Retrieved May 16, 2016, from http://www.e-ir.info/2016/05/12/a-comparative-his torical-study-of-the-development-of-a-european-army/\#_ftn1

Union of International Associations. (n.d.). Retrieved June 16, 2016, from http:// www.uia.org/yearbook

Z. Sore, Z. S. (2010). Establishing Regional Integration: The African Union and the European Union. Macalester International, 25(13). Retrieved May 16, 2016, from http://digitalcommons.macalester.edu/macintl/vol25/ iss $1 / 13$

Zweifel, T. D. (2006). International organizations and democracy: Accountabil ity, politics, and power. Boulder, CO: L. Rienner.

\section{(Footnotes)}

${ }^{1}$ Article II of the OAU Charter: http://www.au.int/en/sites/default/files/treaties/7759-sl-oau_charter_1963_0.pdf

${ }^{2}$ Article 3 of Constitutive Act of the African Union: http://www.au.int/en/sites/ default/ files/ ConstitutiveAct_EN.pdf 